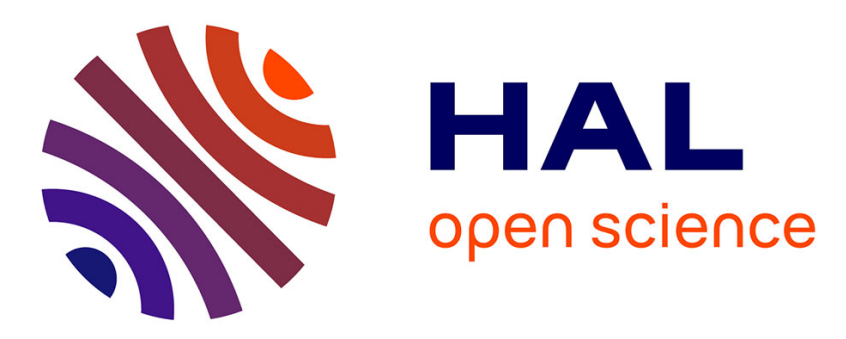

\title{
Evidence of the in vitro genotoxicity of methyl-pyrazole pesticides in human cells.
}

\author{
Vanessa Graillot, Florence Tomasetig, Jean Pierre J. P. Cravedi, Marc
}

Audebert

\section{- To cite this version:}

Vanessa Graillot, Florence Tomasetig, Jean Pierre J. P. Cravedi, Marc Audebert. Evidence of the in vitro genotoxicity of methyl-pyrazole pesticides in human cells.. Mutation Research-Fundamental and Molecular Mechanisms of Mutagenesis, 2012, 748 (1-2), pp.8-16. 10.1016/j.mrgentox.2012.05.014 . hal-02645661

\section{HAL Id: hal-02645661 \\ https://hal.inrae.fr/hal-02645661}

Submitted on 29 May 2020

HAL is a multi-disciplinary open access archive for the deposit and dissemination of scientific research documents, whether they are published or not. The documents may come from teaching and research institutions in France or abroad, or from public or private research centers.
L'archive ouverte pluridisciplinaire HAL, est destinée au dépôt et à la diffusion de documents scientifiques de niveau recherche, publiés ou non, émanant des établissements d'enseignement et de recherche français ou étrangers, des laboratoires publics ou privés. 


\title{
Mutation Research/Genetic Toxicology and Environmental Mutagenesis
}

journal homepage: www.elsevier.com/locate/gentox

\section{Evidence of the in vitro genotoxicity of methyl-pyrazole pesticides in human cells}

\author{
Vanessa Graillot $^{\mathrm{a}, \mathrm{b}}$, Florence Tomasetig ${ }^{\mathrm{a}, \mathrm{b}}$, Jean-Pierre Cravedi ${ }^{\mathrm{a}, \mathrm{b}}$, Marc Audebert ${ }^{\mathrm{a}, \mathrm{b}, *}$ \\ a INRA, UMR1331, Toxalim, Research Centre in Food Toxicology, F-31027 Toulouse, France \\ b Université de Toulouse, INP, ENVT, EIP, UPS, UMR1331, Toxalim, F-31076 Toulouse, France
}

\section{A R T I C L E I N F O}

\section{Article history:}

Received 6 October 2011

Received in revised form 4 April 2012

Accepted 25 May 2012

Available online $\mathrm{xxx}$

\section{Keywords:}

Pyrazole

Pesticides

Genotoxicity

$\gamma$-H2AX

Jurkat cells

SH-SY5Y cells

\begin{abstract}
A B S T R A C T
Consumers are exposed daily to several pesticide residues in food, which can be of potential concern for human health. Based on a previous study dealing with exposure of the French population to pesticide residues via the food, we selected 14 pesticides frequently found in foodstuffs, on the basis of their persistence in the environment or their bioaccumulation in the food chain. In a first step, the objective of this study was to investigate if the 14 selected pesticides were potentially cytotoxic and genotoxic. For this purpose, we used a new and sensitive genotoxicity assay (the $\gamma \mathrm{H} 2 \mathrm{AX}$ test, involving phosphorylation of histone H2AX) with four human cell lines (ACHN, SH-SY5Y, LS-174T and HepG2), each originating from a potential target tissue of food contaminants (kidney, nervous system, colon, and liver, respectively). Tebufenpyrad was the only compound identified as genotoxic and the effect was only observed in the SH-SY5Y neuroblastoma cell-line. A time-course study showed that DNA damage appeared early after treatment $(1 \mathrm{~h})$, suggesting that oxidative stress could be responsible for the induction of $\gamma \mathrm{H} 2 \mathrm{AX}$. In a second step, three other pesticides were studied, i.e. bixafen, fenpyroximate and tolfenpyrad, which - like tebufenpad - also had a methyl-pyrazole structure. All these compounds demonstrated genotoxic activity in SH-SY5Y cells at low concentration (nanomolar range). Complementary experiments demonstrated that the same compounds show genotoxicity in a human T-cell leukemia cell line (Jurkat). Moreover, we observed an increased production of reactive oxygen species in Jurkat cells in the presence of the four methyl-pyrazoles. These results demonstrate that tebufenpyrad, bixafen, fenpyroximat and tolfenpyrad induce DNA damage in human cell lines, very likely by a mode of action that involves oxidative stress. Nonetheless, additional in vivo data are required before a definitive conclusion can be drawn regarding hazard prediction to humans.
\end{abstract}

(C) 2012 Elsevier B.V. All rights reserved.

\section{Introduction}

The widespread use of pesticides to control agricultural pests leads to the presence of residues in the food chain, and consumers can be exposed daily to low levels of these chemicals. Recently, the European Food Safety Authority (EFSA) reported that pesticide residues were detected in $46.7 \%$ of 67,887 food samples analysed throughout the European Union in 2008 [1]. Several epidemiological studies published during the last two decades suggest harmful effects of pesticides on human health, including a possible relationship between pesticide use and cancers such as non-Hodgkin lymphoma, leukaemia, and various types of solid tumour. Many of these effects have been related to occupational exposures $[2,3]$. Nevertheless, whether similar associations exist in the general

\footnotetext{
* Corresponding author at: INRA, UMR1331, Toxalim, 180 Chemin de Tournefeuille BP 93173, 31027 Toulouse Cedex 3, France. Tel.: +33 561285 008; fax: +33 561285244

E-mail address: marc.audebert@toulouse.inra.fr (M. Audebert).
}

population with lifetime exposure to very low doses of pesticides is not known.

The double-strand break (DSB) is considered to be the DNA damage that is most deleterious to the cell. The occurrence of DSBs may start the carcinogenic process if the damage is not properly repaired [4]. After induction of a DSB in DNA, a cell-signalling pathway is set in motion, resulting in the phosphorylation of histone $\mathrm{H} 2 \mathrm{AX}$, to form a product called $\gamma \mathrm{H} 2 \mathrm{AX}$. It has been shown that oxidative stress can induce this phosphorylation [5]. This early and sensitive marker originates from various types of DNA damage, such as DNA adducts, DNA single-strand breaks, DNA replication, or transcription-blocking lesions [6]. It was also reported that micronucleus formation is correlated with $\mathrm{H} 2 \mathrm{AX}$ phosphorylation [7] and that $\gamma \mathrm{H} 2 \mathrm{AX}$ is a reliable biomarker of pre-cancerous cells in vivo [8,9]. These data support the assumption that $\mathrm{H} 2 \mathrm{AX}$ phosphorylation could be an appropriate biomarker of genotoxicity, as suggested in recent in vitro and in vivo studies [10-19].

In a previous study, a statistical method was developed in order to define pesticides that were present in the French diet in 2006, thus relevant to be studied in terms of effects on human health [20]. Briefly, this method was based on exposure to different 
Table 1

Category and chemical class of the 14 active substances studied.

\begin{tabular}{lll}
\hline Active substance & Category & Chemical class \\
\hline Acrinathrin & Acaricide, insecticide & Pyrethroid \\
Benalaxyl & Fungicide & Acylalanine \\
Bupirimate & Fungicide & Pyrimidinol \\
Chlordane & Insecticide & Cyclodiene, organochlorine \\
Dieldrin & Insecticide & Cyclodiene, organochlorine \\
Esfenvalerate & Insecticide & Pyrethroid \\
Heptachlor & Insecticide & Cyclodiene, organochlorine \\
Lindane & Insecticide & Organochlorine \\
Myclobutanil & Fungicide & Triazole \\
Penconazole & Fungicide & Triazole \\
Pirimicarb & Insecticide & Carbamate \\
Propyzamide & Herbicide & Benzamide \\
Pyriproxyfen & Insecticide & Unclassified \\
Tebufenpyrad & Insecticide & Methyl-pyrazole \\
\hline
\end{tabular}

pesticides estimated from data collected by the French national food-monitoring administration, and from data on the dietary habits from a French consumption survey [21,22]. After modelling, two sub-populations were identified that were highly exposed to 34 compounds [20]. In our study, we retained three criteria to determine which pesticides would be analyzed for toxic potential among the 34 compounds. Twenty-one pesticides that the two highly exposed population clusters had in common were first retained in the list. Then, from these 21 pesticides, we retained at least 14 compounds: ten pesticides registered in the Annex I of the 2008 European directive 91/414 (benalaxyl, esfenvalerate, penconazole, pirimicarb, propyzamide, pyriproxyfen, tebufenpyrad), three for which the use was still authorized in 2008 (acrinathrin, bupirimate, myclobutanil), and four pesticides that were considered to be persistent in the environment [23] (dieldrin, chlordane, lindane, heptachlor) (Table 1$)$.

The aim of this study was to screen the cytotoxicity and genotoxicity of the 14 selected pesticides with the $\gamma \mathrm{H} 2 \mathrm{AX}$ In Cell Western (ICW) assay $[10,11,18,19]$. The advantage of the ICW methodology is the simultaneous determination of cytotoxicity and genotoxicity of xenobiotics on cells cultured in a 96-well plate format $[10,11]$. Four human cell lines (ACHN, SH-SY5Y, LS-174T, HepG2) were used, each originating from a potential target tissue of food contaminants, i.e. kidney, nerve tissue, colon and liver, respectively. In a second step, in view of the fact that tebufenpyrad was found positive in our assay, other methyl-pyrazole pesticides, namely bixafen, fenpyroximate and tolfenpyrad, were added to the list of compounds to investigate.

\section{Materials and methods}

\subsection{Chemicals and supplements for cell-culture media}

Tolfenpyrad (purity 99\%) was obtained from CIL (Cluzeau Info Labo, Ste-Foyla-Grande, France) and diluted in dimethyl sulfoxide (DMSO) (Sigma-Aldrich, Saint-Quentin Falavier, France). All other pesticides (purity $>98 \%$ ), as well as benzo[a]pyrene $(\mathrm{B}[a] \mathrm{P})$, camptothecin and etoposide were purchased from Sigma-Aldrich, and diluted also in DMSO. Penicillin, streptomycin, trypsin, PBS, RNAse A (R6513, DNase-free), and Triton X-100 were also obtained from SigmaAldrich. The phosphatase inhibitor cocktail tablets ("PHOSSTOP") were from Roche and the blocking solution (MAXblock Blocking Medium) was from Active Motif (Belgium). TO-PRO-3 iodide (diluted in 1/500 in PST (PBS, $2 \%$ fetal calf serum, $0.2 \%$ Triton X-100)) was purchased from Molecular Probes (Eugene, Oregon, USA).

\subsection{Antibodies}

\subsubsection{Primary antibodies}

Monoclonal anti-phospho-H2AX from rabbit was purchased from Cell Signalling Technology (Danvers, MA, USA) and diluted in $1 / 200$ in PBS containing $2 \%$ fetal bovine serum (FBS) and $0.2 \%$ Triton $\mathrm{X}-100$.

\subsubsection{Secondary antibodies}

Goat anti-rabbit antibody coupled with 770-nm fluorophore (diluted 1/1000 in PST buffer) was purchased from Biotium (CA, USA).

\subsection{Cells lines and maintenance}

SH-SY5Y human neuroblastoma cells were maintained in DMEM/F12 medium, with $10 \% \mathrm{FBS}, 100 \mathrm{U} / \mathrm{ml}$ penicillin and $100 \mu \mathrm{g} / \mathrm{ml}$ streptomycin. ACHN human renal adenocarcinoma cells (ATCC nr. CRL-1611), HepG2 human hepatoblastoma cells (ATCC nr. HB-8065), and LS-174T human epithelial colorectal adenocarcinoma cells (ATCC nr. CL-188) were grown in $\alpha$-MEM medium, supplemented with $10 \%$ FBS and antibiotics $(100 \mathrm{U} / \mathrm{ml}$ penicillin and $100 \mu \mathrm{g} / \mathrm{ml}$ streptomycin). Jurkat T lymphocytes (ATCC nr. TIB-152) were grown in RPMI medium, supplemented with $10 \%$ FBS and antibiotics. All cell lines were grown in a humidified atmosphere with $5 \% \mathrm{CO}_{2}$ at $37^{\circ} \mathrm{C}$.

\subsection{Pesticide treatment}

For the HepG2, ACHN, LS-174T and SH-SY5Y cell lines, $2.6 \times 10^{4}, 4 \times 10^{4}$ $3.2 \times 10^{4}$ and $4 \times 10^{4}$ cells per well, respectively, were grown for $16 \mathrm{~h}$ in 96 -well plates containing $200 \mu \mathrm{L}$ medium per well. Then, the medium was replaced by pesticide solutions diluted in medium without serum, and cells were exposed to $0.2 \%$ $(\mathrm{v} / \mathrm{v})$ DMSO in culture medium.

For the screening of genotoxicity of the 14 compounds, cells were incubated for $24 \mathrm{~h}$ with different concentrations of pesticides according to their solubility. Experiments were carried out in duplicate. For the kinetics, SH-SY5Y cells were exposed from $30 \mathrm{~min}$ to $24 \mathrm{~h}$ to tebufenpyrad with four non-cytotoxic concentrations. Then, cytotoxic and genotoxic activities of bixafen, fenpyroximate and tolfenpyrad were studied after $24 \mathrm{~h}$ of treatment.

For the Jurkat cell line, $3.6 \times 10^{4}$ cells per well were placed in 96 -well plates with RPMI without FBS and treated on the same day with three concentrations of bixafen, fenpyroximate, tebufenpyrad and tolfenpyrad. Then, genotoxic effects were determined after $24 \mathrm{~h}$ of treatment.

\subsection{In Cell Western (ICW) technique}

The In Cell Western technique was previously reported to allow the determination of cell viability in parallel to genotoxicity for adherent cells (ACHN, HepG2, LS-174T and SH-SY5Y) $[10,11,18,19]$. Briefly, after treatment with pesticides, cells were fixed with $4 \%$ paraformaldehyde (Electron Microscopy Science) for $20 \mathrm{~min}$ for adherent cells. Then, cells were permeabilized with $0.2 \%$ Triton X-100 in PBS for five min and blocked with MAXblock blocking medium with PHOSSTOP and RNAse A $(0.1 \mathrm{~g} / \mathrm{L})$ for $60 \mathrm{~min}$ at room temperature. Cells were incubated for $2 \mathrm{~h}$ with the primary antibody in PST buffer and after three 5-min washes in PST, a secondary detection was carried out with secondary antibody mixed with TO-PRO-3 iodide for DNA labelling. After $1 \mathrm{~h}$ of incubation and three 5-min washes in PST, the DNA and $\gamma$-H2AX were simultaneously visualized by means of an Odyssey Infrared Imaging Scanner (Li-Cor ScienceTec, Les Ulis, France) with the 680-nm and the 800-nm fluorophore. Relative fluorescence units for $\gamma$-H2AX per cell were divided by the fluorescence per cell for the vehicle controls to determine the modification in H2AX phosphorylation compared with the control. To measure cytotoxicity, the DNA content in each experiment was compared with that in cell treated with the vehicle control. All experiments were carried out independently, in triplicate. The positive controls used in each treatment were $1 \mu \mathrm{M}$ benzo[a]pyrene for LS-174T and HepG2 cell lines, $1 \mu \mathrm{M}$ camptothecin for Jurkat cells, and $1 \mu \mathrm{M}$ etoposide for ACHN and SH-SY5Y cell lines.

After $24 \mathrm{~h}$ of treatment with pesticides, the Jurkat cells were fixed with $50 \mu \mathrm{L}$ paraformaldehyde ( $4 \%$ final concentration), for $15 \mathrm{~min}$. Then, cells were centrifuged for $10 \mathrm{~min}$ at $1500 \mathrm{rpm}$ at room temperature. The paraformaldehyde was removed and neutralized with $20 \mathrm{mM} \mathrm{NH}_{4} \mathrm{Cl}$ for $2 \mathrm{~min}$. The cells were permeabilized three times with $0.1 \%$ Triton $\mathrm{X}-100$ in PBS and centrifuged for 5 min at $2000 \mathrm{rpm}$ [idem], after blocking the non-specific sites with MAXblock Blocking Medium with PHOSSTOP and RNAse A $(0.1 \mathrm{~g} / \mathrm{L})$ for $60 \mathrm{~min}$. From this step onwards, the ICW protocol was the same as the one described for adherent cells.

\subsection{Quantification of ROS}

Intracellular levels of ROS production were measured with CellROX from Molecular Probes (Eugene, Oregon, USA) according to the manufacturer's instructions. Jurkat cells were treated in the same way as in the ICW technique. Fluorescence intensity was measured with an INFINITEM200 plate reader (TECAN) with excitation at $640 \mathrm{~nm}$ and emission at $655 \mathrm{~nm}$. These experiments were performed in triplicate.

\subsection{Data analysis}

Statistical analyses were performed with Student's $t$-test (one-tailed test). Statistical analysis was performed with the R Software. Error bars represent SEM (standard error of the mean). The statistical significance of the increase in H2AX phosphorylation was determined in comparison with the DMSO control; ${ }^{*} p<0.05$; ${ }^{* *} p<0.01$. 


\section{Results}

\subsection{Cytotoxicity and genotoxicity of the 14 selected pesticides}

In a first step, the cytotoxicity of the 14 selected pesticides was investigated with four human cell lines (HepG2, LS-174T, ACHN and SH-SY5Y) derived from potential target tissues of food contaminants. Due to the limited solubility of acrinathrin, benalaxyl, chlordane, dieldrin, esfenvalerate, lindane, heptachlor in the culture media at $100 \mu \mathrm{M}$, the cytotoxicity of these compounds was not determined at this concentration. The results show that only pirimicarb and propyzamide were non-cytotoxic, irrespective of the concentrations tested with the four human cell lines (Table 2). A cytotoxic effect was observed in at least one of the cell lines for the other 12 test compounds. At high concentrations, some pesticides (bupirimate, myclobutanil, penconazole, and chlordane) were more cytotoxic towards LS-174T and SH-SY5Y cells than to HepG2 and ACHN cells (Table 2).

The genotoxicity of the 14 selected pesticides towards the four cell lines, measured with a genotoxic assay based on histone H2AX phosphorylation, is shown in Figs. 1-4. Genotoxicity was considered to be present if the treatment with the compound resulted in a viability $\geq 80 \%$ and if the induction of $\mathrm{H} 2 \mathrm{AX}$ phosphorylation was statistically at least $20 \%$ higher than that observed with the control DMSO. No induction of genotoxicity was seen with the 14 selected pesticides in ACHN (Fig. 1), HepG2 (Fig. 2) or LS-174T cells (Fig. 3). In the SH-SY5Y cell line (Fig. 4), only tebufenpyrad was found to be genotoxic in a dose-dependent manner $(1-10 \mu \mathrm{M}$; Fig. 4). Because $\gamma \mathrm{H} 2 \mathrm{AX}$ is an early marker of DNA damage, the time course of the genotoxic effect of tebufenpyrad was investigated in these cells (from $30 \mathrm{~min}$ to $24 \mathrm{~h}$ ). DNA damage was observed, on the basis of $\gamma \mathrm{H} 2 \mathrm{AX}$ induction, at $1 \mathrm{~h}$ after the exposure to $100 \mu \mathrm{M}$ of tebufenpyrad (Table 3).

\subsection{Cytotoxicity and potential genotoxicity of other methyl-pyrazole pesticides}

In order to elucidate whether the methyl-pyrazole structure was involved in the genotoxicity of tebufenpyrad (Fig. 5A), three pesticides belonging to the same structural group were investigated, namely bixafen (Fig. 5B), fenpyroximate (Fig. 5C) and tolfenpyrad (Fig. 5D). Cytotoxicity was analyzed by the ICW assay. The cytotoxicity data show that the viability of SH-SY5Y cells at $24 \mathrm{~h}$ was significantly below $80 \%$ for concentrations of fenpyroximate and tebufenpyrad $\geq 3 \mu \mathrm{M}$, whereas for bixafen the $80 \%$ viability threshold was reached for concentrations $\geq 30 \mu \mathrm{M}$ (Fig. 6A-C). As observed with tebufenpyrad, other methyl-pyrazole pesticides (bixafen, fenpyroximate and tolfenpyrad) were found to be genotoxic in a dose-dependent manner in this cell line. Genotoxicity was observed from 3, 1 and $0.01 \mu \mathrm{M}$ for bixafen, fenpyroximate and tolfenpyrad, respectively (Fig. 6A-C).

\subsection{Genotoxic potential of pyrazole pesticide on human lymphocytes}

As tebufenpyrad was demonstrated to be genotoxic on human lymphocytes [24], the genotoxicity of the four methyl-pyrazole pesticides was tested on the Jurkat cell line (human lymphocyte $\mathrm{T}$ cells) (Fig. 7). The four methyl-pyrazole pesticides exhibited similar genotoxic effects on the Jurkat cells as previously found with $\mathrm{SH}-$ SY5Y cells. The weakest effect was observed with bixafen (starting at $10 \mu \mathrm{M}$ ), fenpyroximate was genotoxic at $3 \mu \mathrm{M}$, whereas tolfenpyrad and tebufenpyrad were the most genotoxic test compounds, with a significant induction of DNA damage already observed from $1 \mu \mathrm{M}$ (Fig. 7).

\subsection{ROS production by methyl-pyrazole pesticides on human lymphocytes}

We further investigated if oxidative stress could be responsible for the observed genotoxic effect of the four methyl-pyrazole pesticides (Fig. 7). The production of reactive oxygen species (ROS) was measured in Jurkat cells after treatment with the four methyl-pyrazoles at early time points (Fig. 8). A dose- and timedependent increase of ROS production was observed, irrespective of the methyl-pyrazole tested. The most potent inducer of ROS production was tolfenpyrad, with a significant increase in ROS after $30 \mathrm{~min}$ at $1 \mu \mathrm{M}$ and at all times tested for 10 and $100 \mu \mathrm{M}$ (Fig. 8A-C). Fenpyroximate induced ROS production whatever the time tested at 10 and $100 \mu \mathrm{M}$ (Fig. 8C). Tebufenpyrad induced ROS production only after $1 \mathrm{~h}$ and $2 \mathrm{~h}$ at $100 \mu \mathrm{M}$ (Fig. $8 \mathrm{~B}$ and $\mathrm{C}$ ), whereas this induction was observed after $2 \mathrm{~h}$ at $100 \mu \mathrm{M}$ for bixafen (Fig. 8C). All these data suggest that the genotoxicity of the four methyl-pyrazole compounds is related to the production of reactive oxygen species.

\section{Discussion}

The first objective of this study was to analyse the cytotoxic and genotoxic potential of 14 pesticides chosen among 34 such compounds known to be present in the French diet (based on recently reported French data on their occurrence in food [20]). To reach this goal, we used an approach newly developed in our team, allowing with the same assay the assessment of the cytotoxicity and the genotoxicity of chemicals $[10,11,18,19]$. Because in vitro cell models only express part of the metabolic capabilities expressed in the tissue they originate from, and because they have a different sensitivity to toxic compounds, xenobiotic effects were tested on various human cell lines $[25,26]$. Four human cell lines, derived from potential target organs of food contaminants, were chosen. The cytotoxicity of the 14 selected pesticides was determined by use of the ICW technique. Only pirimicarb and propyzamide were non-cytotoxic in all cell lines tested (concentration range, $0.1-100 \mu \mathrm{M}$ ). In terms of cytotoxicity, SH-SY5Y and LS-174T were the most sensitive cell lines, confirming previously observed results [19].

Considering that only values corresponding to a cell viability $\geq 80 \%$ were taken into account for estimating the genotoxic potential of the 14 test compounds, we found that only tebufenpyrad was genotoxic in a dose-dependent manner on the SH-SY5Y cell line. The negative results obtained for most of the test compounds was expected since pesticides with genotoxic properties are currently banned for agricultural use within the EU. Although limited to SH-SY5Y cells, the significance of the positive outcome obtained with tebufenpyrad at $1 \mu \mathrm{M}$ should be discussed.

In order to verify if the genotoxicity of tebufenpyrad was specific to this compound or could be attributed to the methyl-pyrazole structure, three other pesticides (bixafen, fenpyroximate and tolfenpyrad) with this chemical structure were tested. As observed for tebufenpyrad, the three other methyl-pyrazole pesticides were also genotoxic in SH-SY5Y cells. Bixafen and tebufenpyrad showed similar genotoxic potential, whereas fenpyroximate and tolfenpyrad were genotoxic at concentrations that were 10 - and 100 -fold lower, respectively, than observed for tebufenpyrad. These results suggest that the methyl-pyrazole structure of these compounds is involved in their genotoxic effect.

To the best of our knowledge, current published information on the genotoxic potential of methyl-pyrazole pesticides is very limited. No genotoxic effect of tebufenpyrad was observed with different in vitro regulatory genotoxicity assays, including the Ames test with bacteria, the gene-mutation test with Chinese hamster V79 cells, the assessment of unscheduled DNA synthesis in 


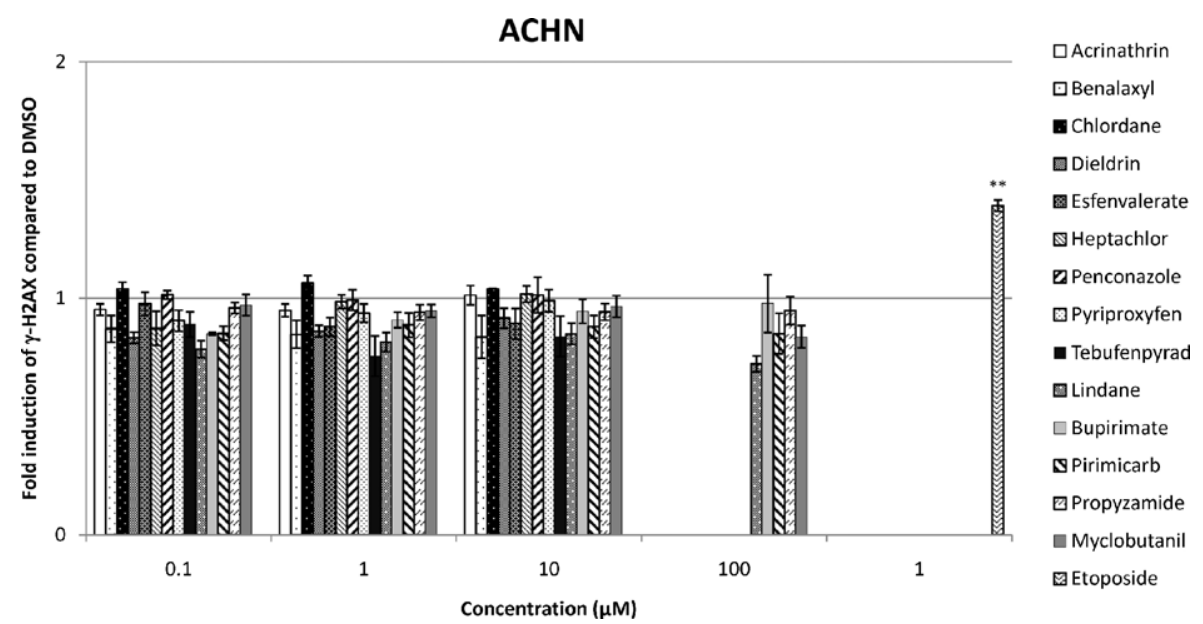

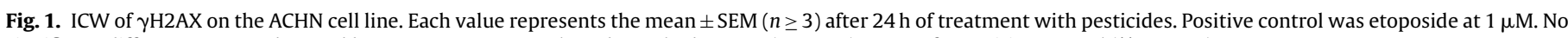
significant differences were observed between DMSO controls and matched groups $(p \geq 0.05)$, except for positive control $\left({ }^{* *} p \leq 0.01\right)$.

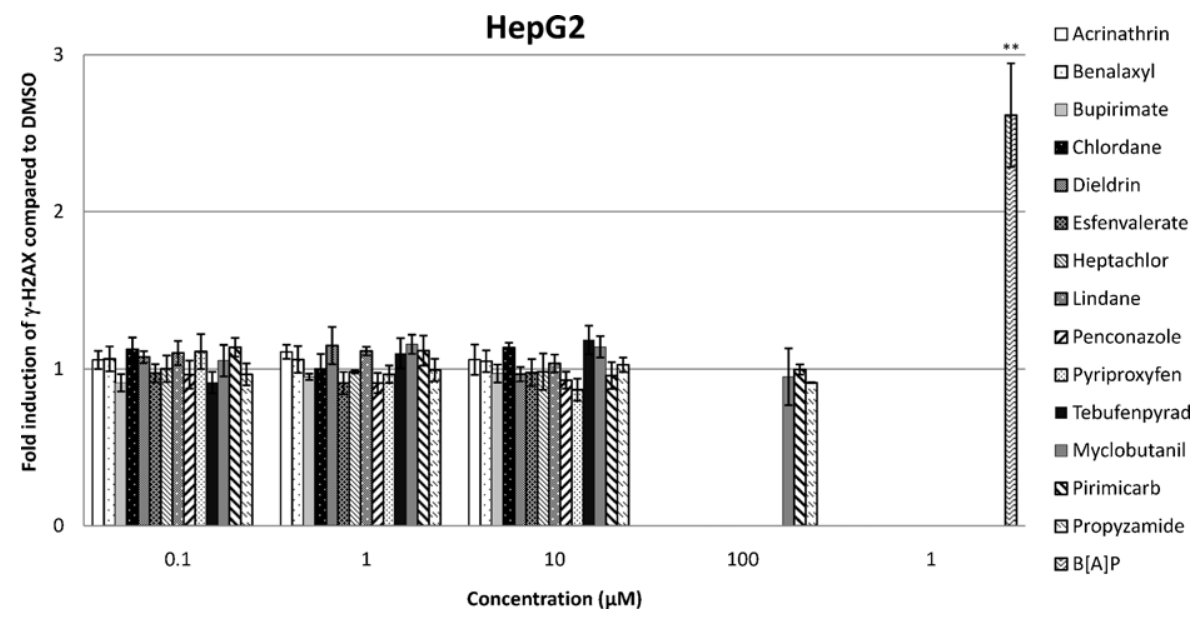

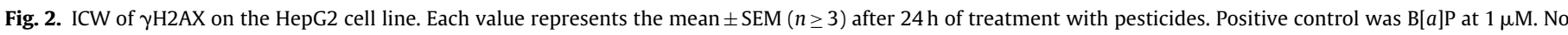
significant differences were observed between DMSO controls and matched groups $(p \geq 0.05)$, except for positive control $(* * p \leq 0.01)$.

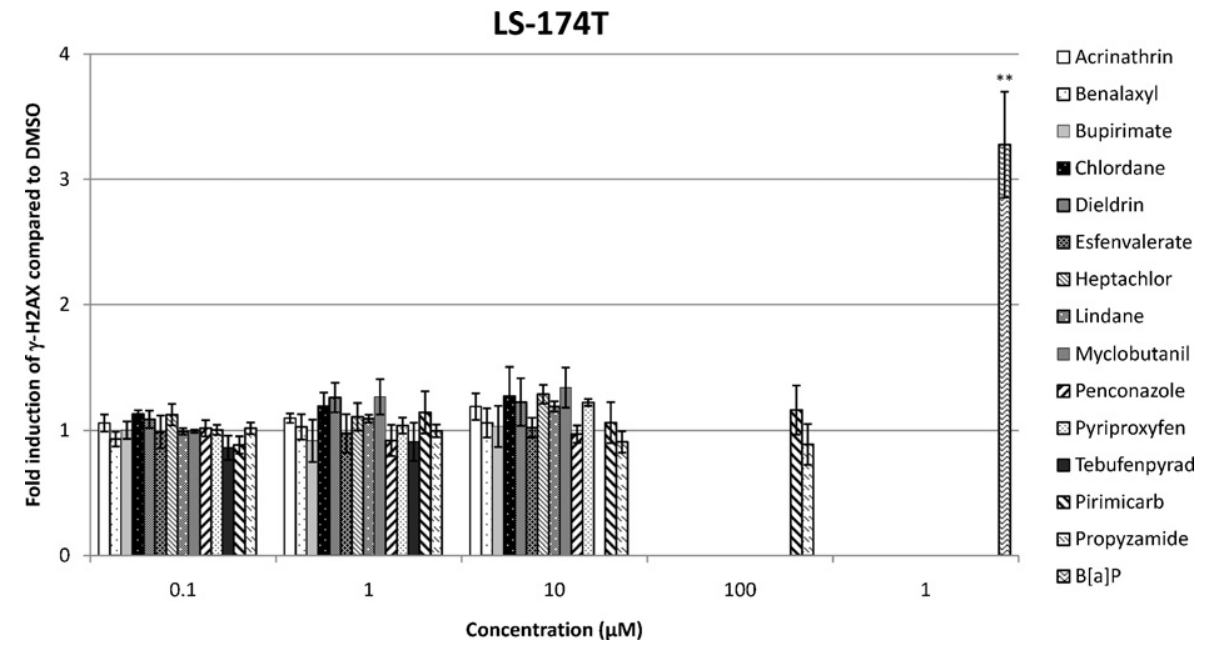

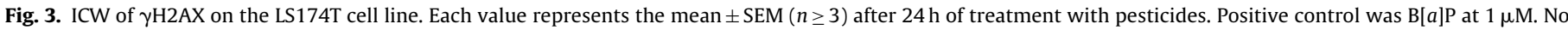
significant differences were observed between DMSO controls and matched groups $(p \geq 0.05)$, except for positive control $\left({ }^{* *} p \leq 0.01\right)$. 
Table 2

Cytotoxicity of the 14 selected pesticides determined with the ICW technique on four human cell lines after $24 \mathrm{~h}$ of treatment.

\begin{tabular}{|c|c|c|c|c|c|}
\hline & $\begin{array}{l}\text { Concentration } \\
(\mu \mathrm{M})\end{array}$ & ACHN & HepG2 & LS174T & SH-SY5Y \\
\hline \multirow[t]{4}{*}{ Esfenvalerate } & 0.1 & $105 \pm 12$ & $112 \pm 38$ & $91 \pm 17$ & $100 \pm 7$ \\
\hline & 1 & $117 \pm 7$ & $106 \pm 34$ & $95 \pm 17$ & $109 \pm 15$ \\
\hline & 10 & $105 \pm 12$ & $89 \pm 19$ & $75 \pm 8^{*}$ & $97 \pm 12$ \\
\hline & 100 & nd & nd & nd & nd \\
\hline \multirow[t]{4}{*}{ Benalaxyl } & 0.1 & $111 \pm 6$ & $97 \pm 15$ & $87 \pm 10$ & $101 \pm 12$ \\
\hline & 1 & $112 \pm 3$ & $96 \pm 17$ & $92 \pm 23$ & $110 \pm 18$ \\
\hline & 10 & $104 \pm 8$ & $98 \pm 19$ & $93 \pm 17$ & $98 \pm 13$ \\
\hline & 100 & nd & nd & nd & nd \\
\hline \multirow[t]{4}{*}{ Propyzamide } & 0.1 & $102 \pm 7$ & $97 \pm 18$ & $99 \pm 13$ & $110 \pm 17$ \\
\hline & 1 & $104 \pm 3$ & $95 \pm 20$ & $87 \pm 11$ & $108 \pm 22$ \\
\hline & 10 & $104 \pm 5$ & $94 \pm 31$ & $94 \pm 27$ & $105 \pm 20$ \\
\hline & 100 & $96 \pm 1^{*}$ & $98 \pm 6$ & $75 \pm 32$ & $105 \pm 25$ \\
\hline \multirow[t]{4}{*}{ Lindane } & 0.1 & $119 \pm 3$ & $83 \pm 9$ & $94 \pm 9$ & $110 \pm 24$ \\
\hline & 1 & $125 \pm 23$ & $87 \pm 9$ & $102 \pm 13$ & $102 \pm 13$ \\
\hline & 10 & $114 \pm 3^{*}$ & $82 \pm 5^{* *}$ & $93 \pm 8$ & $99 \pm 12$ \\
\hline & 100 & nd & nd & nd & nd \\
\hline \multirow[t]{4}{*}{ Pirimicarb } & 0.1 & $115 \pm 6$ & $106 \pm 14$ & $89 \pm 9$ & $95 \pm 5$ \\
\hline & 1 & $111 \pm 7$ & $103 \pm 16$ & $93 \pm 17$ & $94 \pm 10$ \\
\hline & 10 & $110 \pm 5$ & $112 \pm 30$ & $91 \pm 12$ & $108 \pm 17$ \\
\hline & 100 & $99 \pm 6$ & $99 \pm 17$ & $92 \pm 11$ & $110 \pm 17$ \\
\hline \multirow[t]{4}{*}{ Piriproxyfen } & 0.1 & $110 \pm 14$ & $102 \pm 28$ & $88 \pm 5$ & $98 \pm 6$ \\
\hline & 1 & $107 \pm 4$ & $104 \pm 21$ & $88 \pm 6^{*}$ & $88 \pm 14^{*}$ \\
\hline & 10 & $92 \pm 15$ & $101 \pm 20$ & $74 \pm 19$ & $75 \pm 20^{* *}$ \\
\hline & 100 & nd & nd & nd & nd \\
\hline \multirow[t]{4}{*}{ Acrinathrin } & 0.1 & $107 \pm 7$ & $97 \pm 15$ & $98 \pm 17$ & $96 \pm 2$ \\
\hline & 1 & $105 \pm 4$ & $86 \pm 11^{*}$ & $107 \pm 6$ & $96 \pm 19$ \\
\hline & 10 & $92 \pm 7$ & $96 \pm 18$ & $86 \pm 3^{* *}$ & $91 \pm 22$ \\
\hline & 100 & nd & nd & nd & nd \\
\hline \multirow[t]{4}{*}{ Bupirimate } & 0.1 & $114 \pm 12$ & $99 \pm 18$ & $94 \pm 3$ & $94 \pm 6$ \\
\hline & 1 & $109 \pm 11$ & $93 \pm 18$ & $92 \pm 5$ & $107 \pm 29$ \\
\hline & 10 & $108 \pm 17$ & $95 \pm 25$ & $71 \pm 15$ & $92 \pm 26$ \\
\hline & 100 & $74 \pm 16$ & $48 \pm 10^{*}$ & $39 \pm 18^{*}$ & $27 \pm 24^{* *}$ \\
\hline \multirow[t]{4}{*}{ Myclobutanil } & 0.1 & $106 \pm 6$ & $105 \pm 49$ & $94 \pm 11$ & $112 \pm 9$ \\
\hline & 1 & $104 \pm 6$ & $91 \pm 35$ & $86 \pm 20$ & $99 \pm 20$ \\
\hline & 10 & $103 \pm 5$ & $89 \pm 24$ & $83 \pm 17$ & $91 \pm 12$ \\
\hline & 100 & $86 \pm 2^{* *}$ & $77 \pm 17$ & $57 \pm 7^{* *}$ & $88 \pm 21$ \\
\hline \multirow[t]{4}{*}{ Penconazole } & 0.1 & $102 \pm 5$ & $105 \pm 30$ & $94 \pm 12$ & $100 \pm 11$ \\
\hline & 1 & $102 \pm 7$ & $102 \pm 28$ & $71 \pm 9^{*}$ & $105 \pm 20$ \\
\hline & 10 & $98 \pm 8$ & $98 \pm 26$ & $72 \pm 19$ & $101 \pm 21$ \\
\hline & 100 & $70 \pm 21$ & $61 \pm 16$ & $29 \pm 24^{*}$ & $50 \pm 22$ \\
\hline \multirow[t]{4}{*}{ Chlordane } & 0.1 & $100 \pm 1$ & $112 \pm 42$ & $100 \pm 19$ & $103 \pm 13$ \\
\hline & 1 & $98 \pm 7$ & $99 \pm 35$ & $93 \pm 18$ & $106 \pm 14$ \\
\hline & 10 & $97 \pm 13$ & $100 \pm 28$ & $60 \pm 11^{* *}$ & $64 \pm 28^{* *}$ \\
\hline & 100 & nd & nd & nd & nd \\
\hline \multirow[t]{4}{*}{ Dieldrin } & 0.1 & $109 \pm 11$ & $86 \pm 14$ & $97 \pm 21$ & $96 \pm 11$ \\
\hline & 1 & $109 \pm 14$ & $84 \pm 20$ & $88 \pm 7^{*}$ & $101 \pm 24$ \\
\hline & 10 & $103 \pm 17$ & $80 \pm 6^{*}$ & $76 \pm 9^{*}$ & $104 \pm 17$ \\
\hline & 100 & nd & nd & nd & nd \\
\hline \multirow[t]{4}{*}{ Heptachlor } & 0.1 & $103 \pm 19$ & $98 \pm 5$ & $94 \pm 21$ & $96 \pm 10$ \\
\hline & 1 & $100 \pm 16$ & $97 \pm 27$ & $91 \pm 15$ & $109 \pm 24$ \\
\hline & 10 & $92 \pm 16$ & $89 \pm 12$ & $89 \pm 9$ & $90 \pm 19$ \\
\hline & 100 & nd & nd & nd & nd \\
\hline \multirow[t]{4}{*}{ Tebufenpyrad } & 0.1 & $106 \pm 25$ & $87 \pm 20$ & $70 \pm 29$ & $105 \pm 18$ \\
\hline & 1 & $76 \pm 25$ & $74 \pm 18^{*}$ & $65 \pm 19^{* *}$ & $109 \pm 18$ \\
\hline & 10 & $78 \pm 20$ & $65 \pm 22^{*}$ & $49 \pm 15^{* *}$ & $103 \pm 13$ \\
\hline & 100 & $26 \pm 14^{* *}$ & $30.4 \pm 8.4^{*}$ & $13.6 \pm 7.6^{* *}$ & $19 \pm 18^{* *}$ \\
\hline Etoposide & 1 & $90 \pm 8$ & & & $76 \pm 6^{* *}$ \\
\hline Benzo[a]pyrene & 1 & & $92 \pm 14$ & $90 \pm 19$ & \\
\hline
\end{tabular}

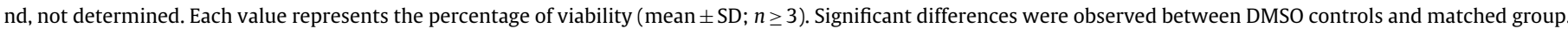
${ }^{*} p \leq 0.05$.

** $p \leq 0.01$

rat primary hepatocytes, and the in vivo mouse bone-marrow erythrocyte test $[24,27,28]$. Nonetheless, cytogenetic experiments realized in vitro on human lymphocytes demonstrated that exposure to tebufenpyrad induced chromatid breaks in the absence of metabolic activation [24,27]. The Food Safety Commission in Japan reports that tolfenpyrad was not genotoxic towards bacteria and no micronuclei in treated mice was observed, but as described with tebufenpyrad, chromosomal aberrations were induced in cultured Chinese hamster lung fibroblast V79 cells [29]. The genotoxicity of fenpyroximate was tested with regulatory genotoxic assay and no genotoxic or clastogenic potential was observed [30,31]. No published data was identified with respect to bixafen genotoxicity. Because US-EPA and the European Chemicals Agency reported that tebufenpyrad was genotoxic on human lymphocytes, showing positive results without S9 liver fraction and equivocal results in the presence of S9 mix [24,27], the genotoxicity of the four methylpyrazole pesticides was tested on human T lymphocytes (Jurkat cell line). We clearly demonstrated that the four methyl-pyrazole pesticides (tebufenpyrad, bixafen, fenpyroximate and tolfenpyrad) were genotoxic in the Jurkat cells with the same genotoxic potential 


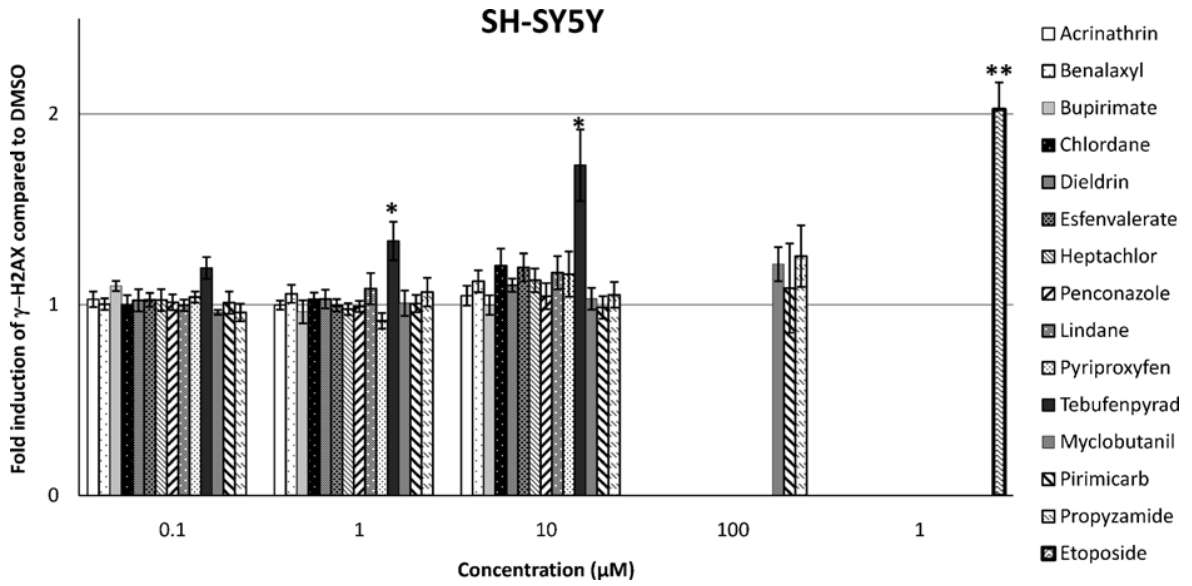

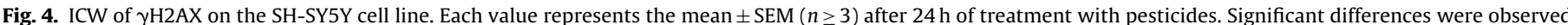
between DMSO controls and matched groups $\left({ }^{*} p \leq 0.05,{ }^{* *} p \leq 0.01\right)$

Table 3

Kinetics of H2AX phosphorylation in the SH-SY5Y cell line treated with tebufenpyrad. The positive control was etoposide at $1 \mu \mathrm{M}$.

\begin{tabular}{|c|c|c|c|c|c|}
\hline \multirow[t]{2}{*}{ Time $(\mathrm{h})$} & \multicolumn{4}{|l|}{ Tebufenpyrad } & \multirow{2}{*}{$\begin{array}{l}\text { Etoposide } \\
1 \mu \mathrm{M}\end{array}$} \\
\hline & $0.1 \mu \mathrm{M}$ & $1 \mu \mathrm{M}$ & $10 \mu \mathrm{M}$ & $100 \mu \mathrm{M}$ & \\
\hline 0.5 & $1.096 \pm 0.28$ & $1.064 \pm 0.08$ & $0.990 \pm 0.04$ & $2.182 \pm 0.97$ & $1.052 \pm 0.14$ \\
\hline 1 & $1.014 \pm 0.16$ & $1.009 \pm 0.21$ & $1.002 \pm 0.24$ & $1.213 \pm 0.07^{* *}$ & $1.308 \pm 0.24$ \\
\hline 2 & $1.185 \pm 0.07$ & $1.113 \pm 0.05$ & $1.160 \pm 0.08$ & $2.514 \pm 1.06^{*}$ & $1.479 \pm 0.37$ \\
\hline 4 & $1.149 \pm 0.10$ & $1.132 \pm 0.08$ & $1.275 \pm 0.43^{*}$ & nd & $1.529 \pm 0.28^{*}$ \\
\hline 8 & $1.211 \pm 0.17$ & $1.191 \pm 0.15$ & $1.436 \pm 0.54^{*}$ & nd & $1.618 \pm 0.27^{*}$ \\
\hline 24 & $1.307 \pm 0.30^{*}$ & $1.363 \pm 0.24^{* *}$ & $1.785 \pm 0.63^{* *}$ & nd & $2.047 \pm 0.50^{* *}$ \\
\hline
\end{tabular}

nd, not determined. Each value represents the mean \pm SEM $(n=5)$. Significant differences were observed between DMSO controls and matched group.

${ }^{*} p \leq 0.05$

$p \leq 0.01$

as observed in the SH-SY5Y cells. A similar sensitivity to toxic xenobiotics of these two cell lines was also demonstrated with different types of compound in two other studies [25,26]. These results confirm the usefulness of screening the toxic effects of compounds in different human cell lines.
Phosphorylation of H2AX is an early and sensitive biomarker resulting from various types of DNA damage [6]. Previously, we demonstrated that DNA damage resulting from DNA-adduct formation by reactive metabolites in cells could be observed from eight hours after treatment $[10,19]$. However, after only one hour<smiles>CCc1nn(C)c(C(=O)NCc2ccc(C(C)(C)C)cc2)c1Cl</smiles>

(B)<smiles>Cn1cc(C(=O)Nc2ccc(F)cc2-c2ccc(Cl)c(Cl)c2)c(C(F)F)n1</smiles>

(D)<smiles>CCc1nn(C)c(C(=O)NCc2ccc(Oc3ccc(C)cc3)cc2)c1Cl</smiles>

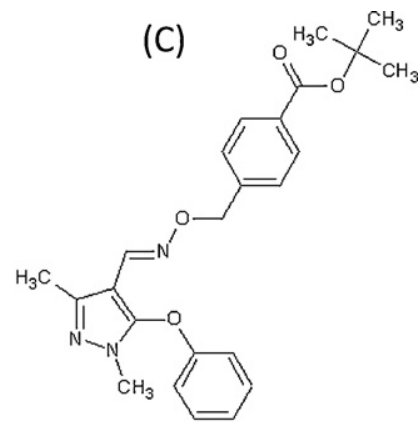

Fig. 5. Chemical structures of methyl-pyrazole pesticides tested in this study. (A) Tebufenpyrad, (B) bixafen, (C) fenpyroximate, (D) tolfenpyrad. 
(A)

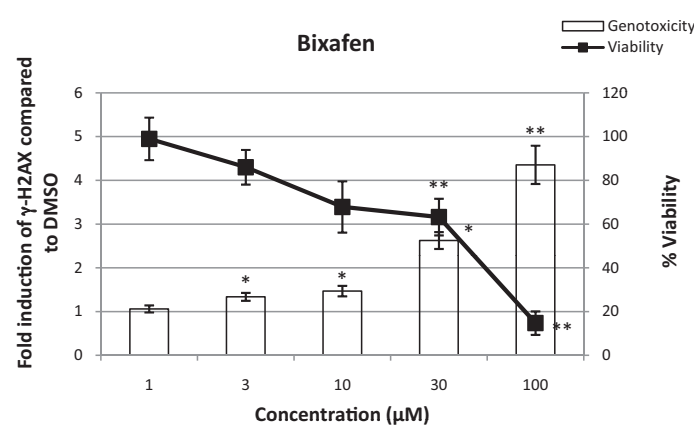

(C)

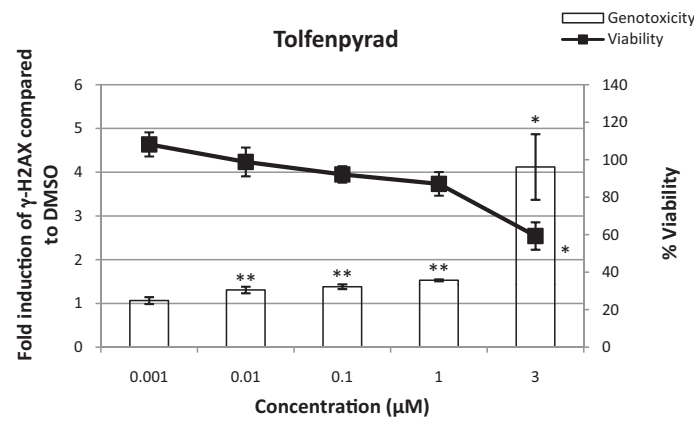

(B)

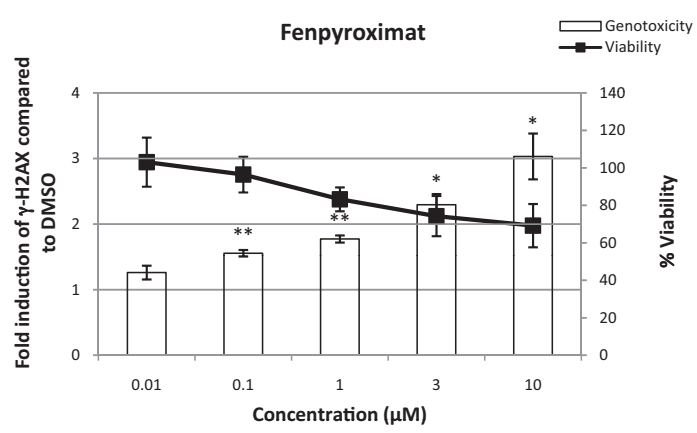

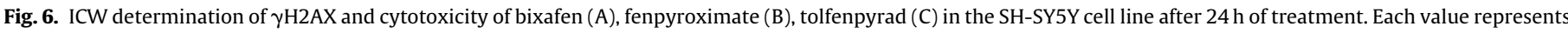
the mean $\pm \operatorname{SEM}(n \geq 3)$. Significant differences were observed between DMSO controls and matched groups $\left({ }^{*} p \leq 0.05,{ }^{* *} p \leq 0.01\right)$.

of exposure to tebufenpyrad, the first DNA damage can already be observed in SH-SY5Y cells. This observation suggests that tebufenpyrad could induce DNA damage without bio-transformation.

Mitochondria are a major source of reactive oxygen species in the cell $[32,33]$. An excessive electron flux or shunting through the mitochondrial respiratory chain may lead to an increase of ROS production and an inhibition of ATP synthesis. Complex I and complex III of the electron-transport chain are the major production sites of oxygen free radicals [34,35]. ROS interact with biomolecules and induce cell disturbance by damaging different cellular components, in particular DNA, proteins, and lipids. Many xenobiotics, including pesticides, can induce ROS production [36-38]. ROS were quantified in Jurkat cells after methyl-pyrazole treatment (Fig. 8), showing that the four test compounds were able to induce oxidative stress.
Moreover, treatments resulting in the highest production of ROS (Fig. 8) also result in the strongest genotoxic response observed with H2AX phosphorylation (Fig. 7).

Tebufenpyrad is an inhibitor of complex I of the mitochondrial electron transport in insects and mites [24], but it was suggested that this compound is also able to inhibit the complex I of human mitochondria. Sherer and collaborators have demonstrated that mitochondrial electron-transport inhibitors, such as the pesticides tebufenpyrad and fenpyroximate, could deplete ATP in human neuroblastoma cells [34]. Moreover, these authors observed oxidative damage with two other pesticides, i.e. rotenone and pyridaben. In several other studies the same response was seen with mitochondrial electron-transport inhibitors $[33,39,40]$. Fenpyroximate and tolfenpyrad have the same mechanism of action as tebufenpyrad

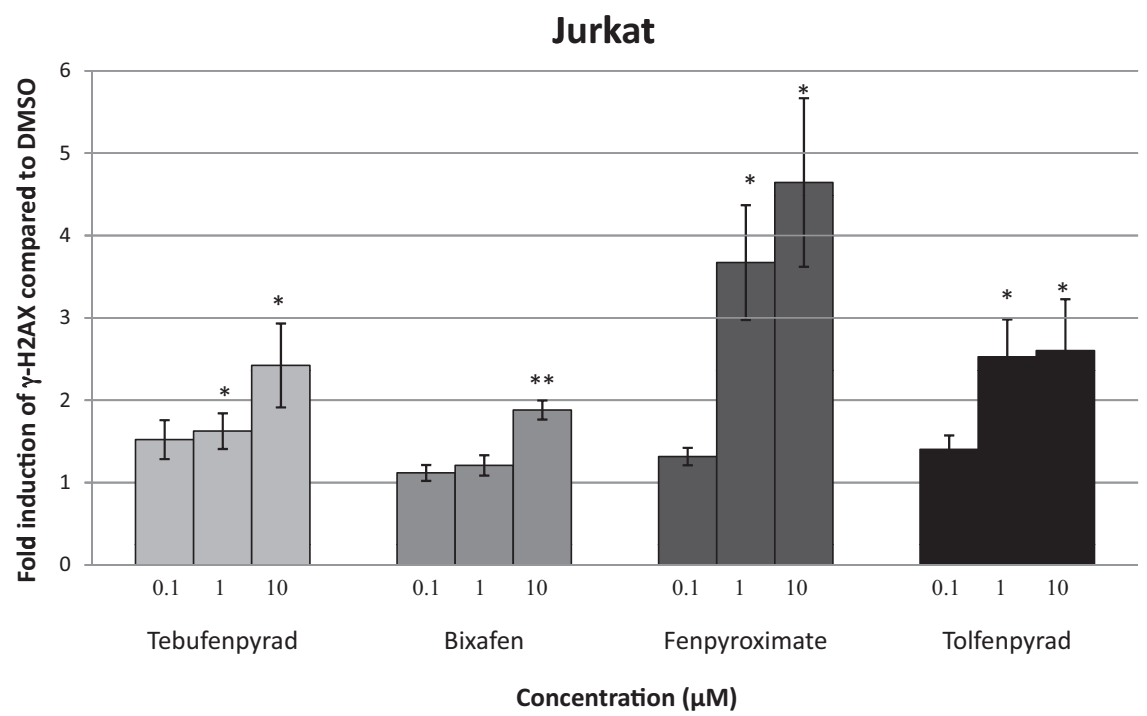

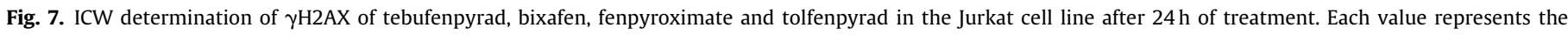
mean $\pm \operatorname{SEM}(n \geq 3)$. Significant differences were observed between DMSO controls and matched groups $\left({ }^{*} p \leq 0.05,{ }^{* *} p \leq 0.01\right)$. 
(A)

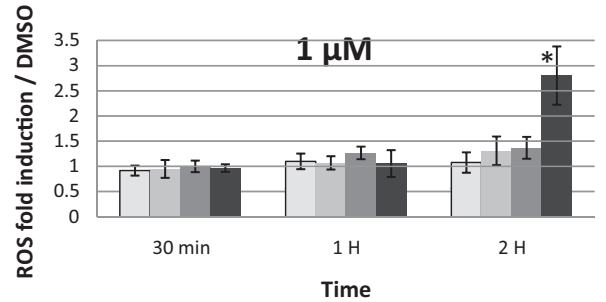

(B)

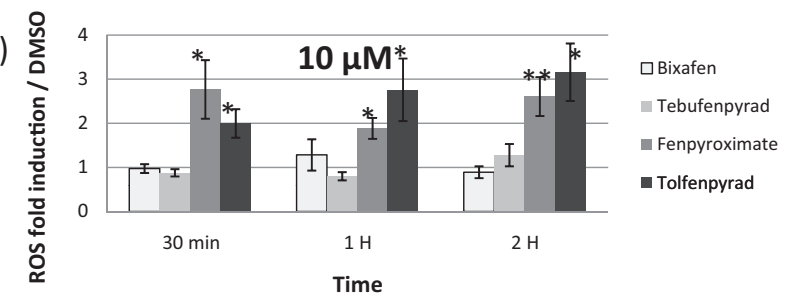

(C)

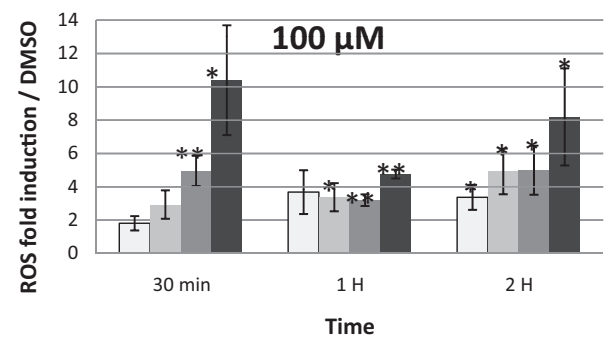

Fig. 8. Determination of reactive oxygen species after treatment with tebufenpyrad, bixafen, fenpyroximate and tolfenpyrad in Jurkat cell line. Cells were treated with tebufenpyrad, bixafen, fenpyroximate or tolfenpyrad for $30 \mathrm{~min}, 1 \mathrm{~h}$ or $2 \mathrm{~h}$, at three different concentrations (A) $1 \mu \mathrm{M},(\mathrm{B}), 10 \mu \mathrm{M}$ and (C) $100 \mu \mathrm{M}$. Each value represents the mean \pm SEM $(n \geq 4)$. Significant differences were observed between DMSO controls and matched group $\left({ }^{*} p \leq 0.05,{ }^{* *} p \leq 0.01\right)$.

(inhibition of complex I in mitochondria in insects), whereas bixafen inhibits complex II. A report from the Japanese Food Safety Commission indicated that tolfenpyrad can inhibit the respiration mitochondrial complex I in vivo and in vitro [29]. Like with tebufenpyrad, it was shown that fenpyroximate could deplete ATP in neuroblastoma cells [34]. No data are accessible about the capacity of bixafen to inhibit the human mitochondrial electron-transport chain, but bixafen inhibited complex II of the mitochondria and it can be assumed that this effect could result in oxidative damage [41]. As for fenpyroximate, tebufenpyrad and tolfenpyrad, the genotoxic mechanism observed for bixafen in our study may be linked to the inhibition of the mitochondrial respiratory system, resulting in ROS production and subsequent oxidative DNA damage.

In our study, tebufenpyrad did not induce DNA damage in ACHN, LS-174T or HepG2 cells. It can be speculated that the negative results obtained with ACHN cells could be explained either by an efficient DNA repair or by a lower sensitivity to ROS due to higher ROS inactivation rates in this cell line, as compared with SH-SY5Y or Jurkat cells. Negative results obtained with HepG2 and LS-174T cells could be explained by their biotransformation capabilities, mainly resulting in the production of inactive metabolites [10,42], unable to inhibit the complex I of the mitochondrial electron chain and to induce ROS production.

\section{Conclusion}

The above data confirm that the H2AX assay may be more sensitive than the genotoxicity tests currently used $[7,18,19,43-45]$. Moreover, we confirm that this assay is well adapted to screening of the genotoxicity of compounds in different human cell lines; potentially it could be used for high-throughput screening purposes
[25,26]. Although this study corroborates the fact that the pesticides to which consumers are exposed via food give no evidence of a genotoxic response in most of the assays, it also shows genotoxic effects in two human cell lines for tebufenpyrad, as well as for three other methyl-pyrazole pesticides. Oxidative stress may play a role in this effect, but the reason why this effect was observed specifically in SH-SY5Y and Jurkat cells remains to be investigated. In any case, more in vivo data are required before a general recommendation can be made regarding the potential hazards of tebufenpyrad, bixafen, fenpyroximate and tolfenpyrad to humans.

\section{Conflict of interests}

The authors are not aware of any conflicts of interests.

\section{Acknowledgements}

This research was funded by the ANSES PNREST program (PESTIMPACT Contract $\mathrm{N}^{\circ}$ EST-010/2/085) and the French "Agence Nationale pour la Recherche" (ANR PERICLES № 2008-CESA 01601).

\section{References}

[1] EFSA, Annual Report on Pesticide Residues according to Article 32 of Regulation (EC) $\mathrm{n}^{\circ} 396 / 2005,2010$.

[2] M. Merhi, H. Raynal, E. Cahuzac, F. Vinson, J.P. Cravedi, L. Gamet-Payrastre, Occupational exposure to pesticides and risk of hematopoietic cancers: metaanalysis of case-control studies, Cancer Causes Control 18 (2007) 1209-1226.

[3] S. Weichenthal, C. Moase, P. Chan, A review of pesticide exposure and cancer incidence in the Agricultural Health Study cohort, Environ. Health Perspect. 118 (2010) 1117-1125.

[4] K.K. Khanna, S.P. Jackson, DNA double-strand breaks: signaling, repair and the cancer connection, Nat. Genet. 27 (2001) 247-254.

[5] T. Tanaka, H.D. Halicka, X. Huang, F. Traganos, Z. Darzynkiewicz, Constitutive histone H2AX phosphorylation and ATM activation, the reporters of DNA damage by endogenous oxidants, Cell Cycle 5 (2006) 1940-1945.

[6] O.A. Sedelnikova, C.E. Redon, J.S. Dickey, A.J. Nakamura, A.G. Georgakilas, W.M. Bonner, Role of oxidatively induced DNA lesions in human pathogenesis, Mutat. Res. 704 (2011) 152-159.

[7] T. Yoshikawa, G. Kashino, K. Ono, M. Watanabe, Phosphorylated H2AX foci in tumor cells have no correlation with their radiation sensitivities, J. Radiat. Res. (Tokyo) 50 (2009) 151-160.

[8] J. Bartkova, Z. Horejsi, K. Koed, A. Kramer, F. Tort, K. Zieger, P. Guldberg, M. Sehested, J.M. Nesland, C. Lukas, T. Orntoft, J. Lukas, J. Bartek, DNA damage response as a candidate anti-cancer barrier in early human tumorigenesis, Nature 434 (2005) 864-870.

[9] V.G. Gorgoulis, L.V. Vassiliou, P. Karakaidos, P. Zacharatos, A. Kotsinas, T. Liloglou, M. Venere, R.A. Ditullio Jr., N.G. Kastrinakis, B. Levy, D. Kletsas, A. Yoneta, M. Herlyn, C. Kittas, T.D. Halazonetis, Activation of the DNA damage checkpoint and genomic instability in human precancerous lesions, Nature 434 (2005) 907-913.

[10] M. Audebert, L. Dolo, E. Perdu, J.P. Cravedi, D. Zalko, Use of the gammaH2AX assay for assessing the genotoxicity of bisphenol $\mathrm{A}$ and bisphenol $\mathrm{F}$ in human cell lines, Arch. Toxicol. 85 (2011) 1463-1473.

[11] M. Audebert, A. Riu, C. Jacques, A. Hillenweck, E.L. Jamin, D. Zalko, J.P. Cravedi, Use of the gammaH2AX assay for assessing the genotoxicity of polycyclic aromatic hydrocarbons in human cell lines, Toxicol. Lett. 199 (2010) 182-192.

[12] K. Matsuzaki, A. Harada, A. Takeiri, K. Tanaka, M. Mishima, Whole cell-ELISA to measure the gammaH2AX response of six aneugens and eight DNA-damaging chemicals, Mutat. Res. 700 (2010) 71-79.

[13] E.P. Rogakou, D.R. Pilch, A.H. Orr, V.S. Ivanova, W.M. Bonner, DNA doublestranded breaks induce histone H2AX phosphorylation on serine 139, J. Biol. Chem. 273 (1998) 5858-5868.

[14] D.J. Smart, K.P. Ahmedi, J.S. Harvey, A.M. Lynch, Genotoxicity screening via the gammaH2AX by flow assay, Mutat. Res. 715 (2011) 25-31.

[15] T. Tanaka, H.D. Halicka, F. Traganos, Z. Darzynkiewicz, Phosphorylation of histone H2AX on Ser 139 and activation of ATM during oxidative burst in phorbol ester-treated human leukocytes, Cell Cycle 5 (2006) 2671-2675.

[16] G.P. Watters, D.J. Smart, J.S. Harvey, C.A. Austin, H2AX phosphorylation as a genotoxicity endpoint, Mutat. Res. 679 (2009) 50-58.

[17] C. Zhou, Z. Li, H. Diao, Y. Yu, W. Zhu, Y. Dai, F.F. Chen, J. Yang, DNA damage evaluated by gammaH2AX foci formation by a selective group of chemical/physical stressors, Mutat. Res. 604 (2006) 8-18.

[18] M. Audebert, F. Zeman, R. Beaudoin, A. Pery, J.P. Cravedi, Comparative potency approach based on H2AX assay for estimating the genotoxicity of polycyclic aromatic hydrocarbons, Toxicol. Appl. Pharmacol. 260 (2012) 58-64.

[19] V. Graillot, N. Takakura, L.L. Hegarat, V. Fessard, M. Audebert, J.P. Cravedi, Genotoxicity of pesticide mixtures present in the diet of the French population, Environ. Mol. Mutagen. 53 (2012) 173-184. 
[20] A. Crepet, J. Tressou, Bayesian nonparametric model for clustering individual co-exposure to pesticides found in the French diet, Bayesian Anal. 6 (2011) 127-144.

[21] C. Dubuisson, S. Lioret, M. Touvier, A. Dufour, G. Calamassi-Tran, J.L. Volatier, L. Lafay, Trends in food and nutritional intakes of French adults from 1999 to 2007: results from the INCA surveys, Br. J. Nutr. 103 (2010) 1035-1048.

[22] S. Lioret, M. Touvier, M. Balin, I. Huybrechts, C. Dubuisson, A. Dufour, M. Bertin, B. Maire, L. Lafay, Characteristics of energy under-reporting in children and adolescents, Br. J. Nutr. 105 (2011) 1671-1680.

[23] S. Convention Stockholm Convention on Persistent Organic Pollutants, http://www.pops.int/documents/convtext/convtext_en.pdf, 1997.

[24] US-EPA Tebufenpyrad, http://www.epa.gov/opprd001/factsheets/ tebufenpyrad.pdf, 2002.

[25] R. Huang, N. Southall, M.H. Cho, M. Xia, J. Inglese, C.P. Austin, Characterization of diversity in toxicity mechanism using in vitro cytotoxicity assays in quantitative high throughput screening, Chem. Res. Toxicol. 21 (2008) 659-667.

[26] M. Xia, R. Huang, K.L. Witt, N. Southall, J. Fostel, M.H. Cho, A. Jadhav, C.S. Smith, J. Inglese, C.J. Portier, R.R. Tice, C.P. Austin, Compound cytotoxicity profiling using quantitative high-throughput screening, Environ. Health Perspect. 116 (2008) 284-291.

[27] European Chemicals Agency, CLH Report for Tebufenpyrad, http://echa.europa. eu/documents/10162/13626/clh_tebufenpyrad_en.pdf, 2011.

[28] EFSA, Conclusion regarding the peer review of the pesticide risk assessment of the active substance tebufenpyrad, 2008.

[29] Food, Safety, Commission and o. Japan Evalution Report of TOLFENPYRAD, http://www.fsc.go.jp/english/evaluationreports/pesticide/evaluationreport_ tolfenpyrad.pdf, 2004.

[30] EFSA, Conclusion regarding the peer review of the pesticide risk assessment of the active substance fenpyroximate, EFSA Sci. Rep. 192 (2008) 1-100.

[31] IPCS, Fenpyroximate, http://www.inchem.org/documents/jmpr/jmpmono/ v95pr06.htm, 1995.

[32] T. Ide, H. Tsutsui, S. Kinugawa, H. Utsumi, D. Kang, N. Hattori, K. Uchida, K. Arimura, K. Egashira, A. Takeshita, Mitochondrial electron transport complex $\mathrm{I}$ is a potential source of oxygen free radicals in the failing myocardium, Circ. Res. 85 (1999) 357-363.

[33] M.P. Murphy, How mitochondria produce reactive oxygen species, Biochem. J. 417 (2009) 1-13.

[34] T.B. Sherer, J.R. Richardson, C.M. Testa, B.B. Seo, A.V. Panov, T. Yagi, A. MatsunoYagi, G.W. Miller, J.T. Greenamyre, Mechanism of toxicity of pesticides acting at complex I: relevance to environmental etiologies of Parkinson's disease, J. Neurochem. 100 (2007) 1469-1479.

[35] Q. Chen, E.J. Vazquez, S. Moghaddas, C.L. Hoppel, E.J. Lesnefsky, Production of reactive oxygen species by mitochondria: central role of complex III, J. Biol. Chem. 278 (2003) 36027-36031.

[36] J.E. Lee, J.S. Kang, Y.W. Ki, S.H. Lee, S.J. Lee, K.S. Lee, H.C. Koh, Akt/GSK3beta signaling is involved in fipronil-induced apoptotic cell death of human neuroblastoma SH-SY5Y cells, Toxicol. Lett. 202 (2011) 133-141.

[37] A. Slaninova, M. Smutna, H. Modra, Z. Svobodova, A review: oxidative stress in fish induced by pesticides, Neuroendocrinol. Lett. 30 (Suppl. 1) (2009) 2-12.

[38] W.G. Chung, C.L. Miranda, C.S. Maier, Epigallocatechin gallate (EGCG) potentiates the cytotoxicity of rotenone in neuroblastoma SH-SY5Y cells, Brain Res. 1176 (2007) 133-142.

[39] S. Lee, E. Tak, J. Lee, M.A. Rashid, M.P. Murphy, J. Ha, S.S. Kim, Mitochondrial $\mathrm{H}_{2} \mathrm{O}_{2}$ generated from electron transport chain complex I stimulates muscle differentiation, Cell Res. 21 (2011) 817-834.

[40] T.B. Sherer, R. Betarbet, C.M. Testa, B.B.Seo, J.R. Richardson, J.H. Kim, G.W. Miller, T. Yagi, A. Matsuno-Yagi, J.T. Greenamyre, Mechanism of toxicity in rotenone models of Parkinson's disease, J. Neurosci. 23 (2003) 10756-10764.

[41] L.F. Dong, V.J. Jameson, D. Tilly, J. Cerny, E. Mahdavian, A. Marin-Hernandez, L. Hernandez-Esquivel, S. Rodriguez-Enriquez, J. Stursa, P.K. Witting, B. Stantic, J. Rohlena, J. Truksa, K. Kluckova, J.C. Dyason, M. Ledvina, B.A. Salvatore, R. Moreno-Sanchez, M.J. Coster, S.J. Ralph, R.A. Smith, J. Neuzil, Mitochondrial targeting of vitamin E succinate enhances its pro-apoptotic and anti-cancer activity via mitochondrial complex II, J. Biol. Chem. 286 (2010) 3717-3728.

[42] M. Iwanari, M. Nakajima, R. Kizu, K. Hayakawa, T. Yokoi, Induction of CYP1A1, CYP1A2, and CYP1B1 mRNAs by nitropolycyclic aromatic hydrocarbons in various human tissue-derived cells: chemical-, cytochrome P450 isoform-, and cell-specific differences, Arch. Toxicol. 76 (2002) 287-298.

[43] I.H. Ismail, T.I. Wadhra, O. Hammarsten, An optimized method for detecting gamma-H2AX in blood cells reveals a significant interindividual variation in the gamma-H2AX response among humans, Nucleic Acids Res. 35 (2007) e36.

[44] P. Leopardi, E. Cordelli, P. Villani, T.P. Cremona, L. Conti, G. De Luca, R. Crebelli, Assessment of in vivo genotoxicity of the rodent carcinogen furan: evaluation of DNA damage and induction of micronuclei in mouse splenocytes, Mutagenesis 25 (2010) 57-62.

[45] B. Trouiller, R. Reliene, A. Westbrook, P. Solaimani, R.H. Schiestl, Titanium dioxide nanoparticles induce DNA damage and genetic instability in vivo in mice, Cancer Res. 69 (2009) 8784-8789. 